\title{
Fish Sellers Knowledge on Exposure of Mercury from Fish in the Kenjeran Beach Area, Surabaya
}

\author{
Trias Mahmudiono $^{1 *}$ (D), Eurika Zebadia $^{1}$ D, Diah Indriani ${ }^{2} \mathbb{D}$, Stefania Setyaningtyas ${ }^{1}$ (D) \\ ${ }^{1}$ Department of Nutrition, Faculty of Public Health, Universitas Airlangga, Surabaya, Indonesia; ${ }^{2}$ Department of Biostatistics and \\ Population, Public Health Faculty, Universitas Airlangga, Surabaya, Indonesia
}

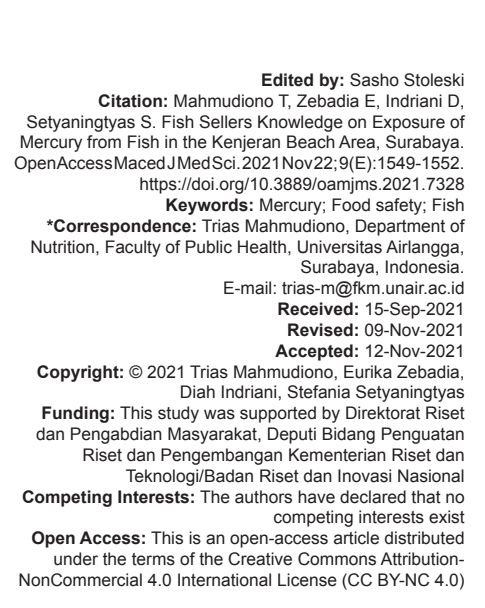

Introduction

Indonesia is geographically a maritime country with the Indonesian livelihood both derives from and depends on the sea. The production of fish in 2020 in Indonesia was approximately 1.549 .963 tons from the sea fisheries production[1]. The fish consumption was increasing throughout 2014-2018 and in 2018; the consumption was approximately $50.69 \mathrm{~kg} /$ capita [2]. Thus, this showed a high consumption of fish that known as one of the high protein food sources. However, the development in industrialization and human activities lead to the degradation of environmental quality causing public health problems related to the safety of fish consumed in areas where industrialization is taking place such as Surabaya city.

One of the concerns on food safety especially in fish is the contamination of mercury. Mercury is one of the highly toxic elements to human health that were released from natural sources (e.g., the volcanic activity, water movements, and biological processes), human activities (e.g., combustion of fossil fuels, electricity-generating power stations, and medical equipment), and remobilization of historic sources (e.g., mercury in soil, sediment, water, and waste) [3]. Methyl mercury is one of the compounds that primarily found in the water [4]. Methyl mercury is one of the compounds that primarily found in the water, thus, caused accumulation of mercury in fish especially in bigger fish according to the food web in the aquatic system [4], [5], [6]. The mercury exposure in human is largely through the ingestion of mercury contaminated fish [4]. Mercury ingestion showed numerous effects to human health such as neurocognitive deficits and neuromotor disabilities, visual impairment, paresthesia, impairments of taste, smell, and hearing [7].

The previous study showed that the coastal area of Surabaya had high contamination level of mercury, thus fish that lived in that environment had higher risk on ingesting heavy metal from gill and its food [8]. The Environmental Health Engineering Center (Balai Teknik Kesehatan Lingkungan) in 2000 found that the concentration of heavy metals such as mercury, lead, and cooper in fish from Kenjeran Beach Area was exceeding the WHO and FAO threshold. Study on mercury contamination in Mackerel fish that sold in Kenjeran Beach area showed that the mercury concentration in fish was ranging from 0.0118 to 0.0287 [9]. 
Besides being the attraction area in Surabaya, Kenjeran Beach also have local port for fisherman. There are several shops near the Kenjeran Beach that sells both fresh fish and processed fish. Typical foods sold by the sellers are sea cucumber chips, shrimp chips, etc. The increased risk of contamination from food can occur due to the low awareness among citizens and food sellers. This study aimed to assess the knowledge levels among sellers pertaining to mercury contamination in fish sold in Kenjeran Beach area, Surabaya.

\section{Methods}

A cross-sectional study design was conducted in this study. The population and samples were taken from eight traditional markets located in Kenjeran beach area, Surabaya that was found to sell fish contaminated with mercury in the previous study. The traditional market map is shown in Figure 1. The traditional marker in this study were Bhinneka Raya market, Bulak Banteng market, Kempeyeng market, Nambangan market, Pogot market, Pusat Ikan Asap market, Sidotopo Wetan Market, and Tambak Wedi market.

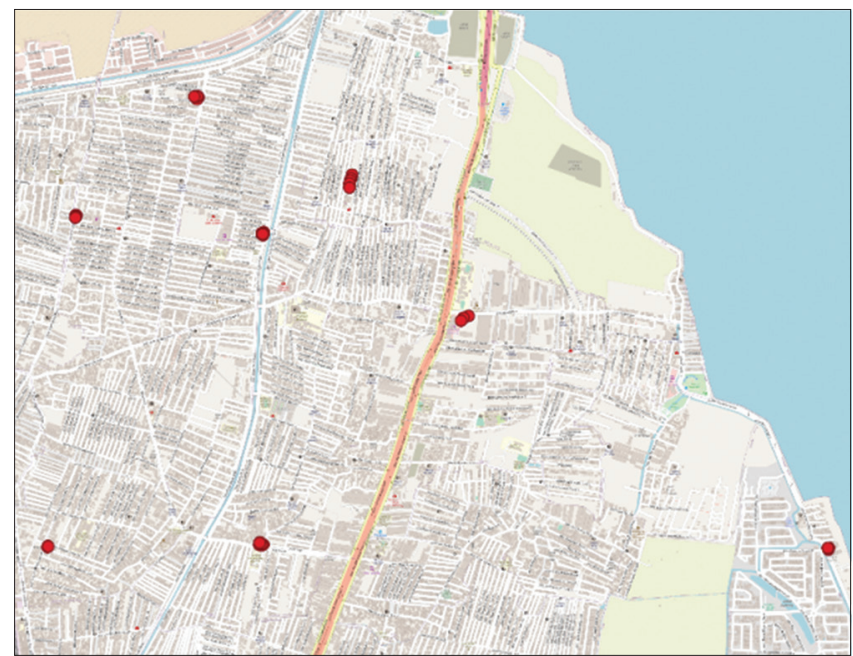

Figure 1: Location of traditional fish markets

There were 72 fish randomly selected and taken to the Sucofindo Analyitical Laboratory from the markets to assess the mercury concentration. A number of 36 sellers were randomly selected and were given questionnaires to assess the level of knowledge on mercury pollution in fish. The questionnaire consisted of ten questions that were scored to assess the mercury contamination knowledge level. The maximum score was 19. The concentration of mercury was categorized as detected and undetected. A descriptive and Chi-square analysis was conducted to know the relationship between the seller's knowledge level and mercury concentration in fish.
Table 1: Characteristics of the respondents

\begin{tabular}{llll}
\hline Variables & $\mathrm{n}$ & $\%$ & Mean \\
\hline Age & 16 & 43.2 & $48.17 \pm 13.65$ \\
$\quad \leq 40$ years old & 21 & 56.8 & \\
$\quad>40$ years old & & 5.6 & \\
Sex & 2 & 94.4 & \\
$\quad$ Male & 34 & 40.6 & $9.22 \pm 7.055$ \\
$\quad$ Female & 15 & 35.1 & \\
Years of selling fish & 13 & 24.3 & \\
$\quad<5$ years & 9 & 8.6 & \\
5-10 years & & 37.1 & \\
$>10$ years & 3 & 17.2 & \\
Frequency of eating fish per week & 13 & 37.1 & \\
$\quad$ Not eating & 6 & & \\
1-3 times & 13 & \\
4-6 times & & & \\
Everyday & &
\end{tabular}

\section{Results and Discussion}

\section{sellers \\ Characteristics and knowledge of the}

The mean age of sellers in our study was $48.17 \pm 13.65$ years old and most of the sellers were female. Most of them were selling fish for less than 5 years (Table 1$)$. More than a half $(55.6 \%)$ of saltwater fish sold by the sellers were found to be contaminated with mercury; meanwhile, a number of $69.4 \%$ freshwater fish were found to be uncontaminated with mercury. The mean mercury concentration in saltwater and freshwater fish that were detected in this study was $0.00686 \pm$ $0.01 \mathrm{ppm}$ and $0.00353 \pm 0.02 \mathrm{ppm}$, respectively (Table 2 ).

\section{Table 2: Results}

\begin{tabular}{lcll}
\hline $\begin{array}{l}\text { Mercury concentration in saltwater fish } \\
\text { Detected }\end{array}$ & 20 & 55.6 & $0.00686 \pm 0.0109 \mathrm{ppm}$ \\
Un-detected & 16 & 44.4 & \\
$\begin{array}{l}\text { Mercury concentration in freshwater } \\
\text { Detected }\end{array}$ & 11 & 30.6 & $0.00353 \pm 0.0150 \mathrm{ppm}$ \\
$\begin{array}{l}\text { Un-detected } \\
\text { Knowledge of the fish sellers }\end{array}$ & 25 & 69.4 & \\
$0-5$ & 9 & 25 & 7.69 \\
$6-10$ & 20 & 55.6 & \\
$11-15$ & 6 & 16.7 & \\
$16-19$ & 1 & 2.8 & \\
\hline
\end{tabular}

The mean questionnaire score in this study was 7.69 and the highest score was 17 out of 19. In our study, more than half of the seller's scores were 6-10 out of 19. This showed that the seller's knowledge of mercury contamination in fish was low. This might be attributed to $86.1 \%$ of sellers and did not know about the potential of mercury contamination in fish. Moreover, $97.2 \%$ of the sellers did not have the basic knowledge of mercury and its route of exposure. However, more than $69 \%$ of sellers could answer the benefits of eating fish, especially for babies and children. This showed that the sellers already knew the benefits of eating fish but had low knowledge of the potential of mercury contamination in fish.

According to the National Agency of Drug and Food Control, the mercury threshold for fish and its products is $0.5 \mathrm{ppm}$ [10]. The results of lab analysis showed that the mean concentration of mercury in saltwater fishes was $0.00686 \pm 0.0109 \mathrm{ppm}$. Although, mercury was detected in most of the seawater fish, this number showed that the mercury contamination in 
saltwater fish from traditional markets near Kenjeran Beach was low compared to the threshold. However, low doses and long exposure to mercury still could accumulate in the body and causes several damages. Low exposure to mercury was found to affect the endocrine system especially causes disruption of insulin, estrogen, testosterone, and adrenaline hormone [11]. Several studies also showed that exposure to mercury could damage the central nervous system and nephrons [7], [11].

\section{Statistical analysis}

In this study, we found the association between bought wholesale fish sourced from Kenjeran Beach Area and the concentration of mercury in saltwater fish that sold by the sellers (Table 3). Based on the laboratory test related to the contamination of mercury found that fish that sold in market near Kenjeran Beach Area, especially the saltwater fish significantly associated with high concentration of mercury. Meanwhile, the freshwater fish are not proven to be significant. A previous study showed that mercury concentration in Kenjeran Beach water was found to be exceeding the threshold of $0.001 \mathrm{ppm}$ and the concentration of mercury contamination in fish sourced from Kenjeran Beach was 0.809 ppm [12]. A recent study in 2016 also showed that the mean mercury concentration in mackerel fish sourced from Kenjeran Beach was 0.019 ppm [9]. This number was higher compared to our study that held in 2020. Thus, from our findings and the results of previous studies, we can conclude that fish sourced from Kenjeran Beach Area was contaminated with mercury.

Table 3: Chi-square test results on variables and concentration of mercury in saltwater fish

\begin{tabular}{ll}
\hline Variables & p-value \\
\hline Bought wholesale fish sourced from Kenjeran Beach Area & $0.024^{*}$ \\
Distance between the seller and nearby school & $0.035^{*}$ \\
Seller's mercury knowledge & 0.063 \\
\hline${ }^{*}$ Statistically significant at alpha<0.05 &
\end{tabular}

In this study, there was a significant relationship between the distance of school and mercury concentration. The distance from fish and the vendors do not directly associated with exposure toward mercury contamination, but the closer the school with the fish sellers, it is believed that it will serve as potential source of contaminated food that might be purchased by the school children or parents. The Chi-square test results on this study showed that there was no association between the seller's knowledge and concentration of mercury in both saltwater and freshwater fish (Tables 3 and Table 4). This could happen because most of the respondent's score was low. This could show that most of the sellers were not aware of mercury contamination in fish. Moreover, there were not any specific physical signs to detect mercury other than running laboratory analysis of the water, fish, and sediments. Therefore, it is hard for the consumers and the sellers to differentiate fish that are contaminated with mercury.
Table 4: Chi-square test results on variables and concentration of mercury in freshwater fish

\begin{tabular}{ll}
\hline Variables & p-value \\
\hline Bought wholesale fish sourced from Kenjeran beach area & 0.057 \\
Distance between the seller and nearby school & 0.080 \\
Seller's mercury knowledge & 0.428 \\
\hline
\end{tabular}

Furthermore, direct and indirect strategies are needed to overcome this problem. Monitoring and evaluation of the mercury levels of water and fish on Kenjeran Beach Area from the Surabaya Environmental Health Service are needed. Furthermore, several strategies to improve public awareness of mercury contamination are suggested especially for the sellers. One of the strategies to reduce the mercury concentration in the fish is by doing the smoking process [13]. A previous study in fish sourced from Kenjeran Beach Area showed that the smoking process could reduce the mercury concentration to $45.4 \%$ [9]. For the consumers, it is very recommended to limit the number of fish consumed per week especially carnivorous and omnivorous fish due to the bigger risk of mercury accumulation in those fish [14].

From our knowledge, this is the first research that assesses the mercury level and the seller's mercury knowledge conducted in traditional markets near Kenjeran Beach area. However, the limitation in our study was we did not specify the species of fish that were analyzed therefore we just generalized the fish into the category of saltwater fish and freshwater fish. Fish that were used in this study were not freshly caught by the seller therefore we did not know the exact time of fish coming out from the water.

\section{Conclusion}

The seller's knowledge of mercury in this study was low. There was no association between the seller's knowledge and the mercury concentration in fish. However, this study highlights the association between buying fish from Kenjeran Beach and fish's mercury contamination. The increased risk of contamination from food can occur due to the low awareness among citizens and food sellers. Therefore, direct and indirect strategies to empower people who live near Kenjeran Beach Area to choose low mercury concentrated fish are needed.

\section{Acknowledgment}

We thank all the panelists involved in this study. The researchers also extend the gratitude to Direktorat Riset dan Pengabdian Masyarakat, Deputi Bidang Penguatan Riset dan Pengembangan Kementerian 
Riset dan Teknologi/Badan Riset dan Inovasi Nasional for funding this study.

\section{References}

1. Ministry of Marine Affairs and Fisheries. Indonesia Fisheries Production; 2018. Available from: https://statistik.kkp.go.id/ home.php?m=total\& $\mathrm{i}=2 \#$ panel-footer [Last accessed on 2021 Sep 08].

2. Ministry of Marine Affairs and Fisheries. Fish Consumption in 2014-2018. Jakarta: Ministry of Marine Affairs and Fisheries; 2018. Available from: https://kkp.go.id/djpdspkp/ artikel/26868-angka-konsumsi-ikan-tahun-2014-2018

3. World Health Organization. Exposure to Mercury: A Major Public Health Concern. Preventing Disease through Healthy Environments. Geneva: World Health Organization; 2006.

4. Saturday A. Mercury and its associated impacts on environment and human health: A review. J Environ Health Sci. 2018;4:37-43.

5. Zhu S, Zhang Z, Žagar D. Mercury transport and fate models in aquatic systems: A review and synthesis. Sci Total Environ 2018;639:538-49. http://doi.org/10.1016/j.scitotenv.2018.04.397 PMid:29800847

6. Canuel R, Lucotte M, de Grosbois SB. Mercury cycling and human health concerns in remote ecosystems in the Americas.
Sapiens. 2009;2(1).

7. Maunsell J. Mercury exposure and children's health. Brain Behav Immun. 2008;22(5):4109.

8. Hutomo LP, Wulandari SY, Marwoto J. Study of the distribution of heavy metal concentrations of $\mathrm{PB}$ and $\mathrm{Cu}$ in sediments at Kenjeran Beach, Surabaya. J Oseanografi. 2016;5(2):277-85

9. Fithriyah A, Rusmiati, Narwati. Differences in levels of heavy metal mercury (hg) in mackerel (Scomberomorus Commerson) sold at Kenjeran beach, Surabaya in 2015. Gema Lingkung Kesehat. 2016;14(1):16-9.

10. National Agency of Drug and Food Control. National Agency of Drug and Food ControlNo. 5/2018 Tentang Batas Maksiumum Cemaran Logam dalam Pangan Olahan Biji-Bijian, Jakarta; 2018.

11. Rice KM, Walker EM, Wu M, Gillette C, Blough ER. Environmenta mercury and its toxic effects. J Prev Med Public Health 2014;47(2):74-83. http://doi.org/10.3961/jpmph.2014.47.2.74 PMid:24744824

12. Taftazani A. Distribusi Konsentrasi Logam Berat $\mathrm{Hg}$ dan $\mathrm{Cr}$ Pada Sampel Lingkungan Perairan Surabaya. In: Prosiding PPI-PDIPTN: 37 dan 44; 2007.

13. Tschakert P. Mercury in fish: A critical examination of gold mining and human contamination in Ghana. Int J Environ Pollut. 2010;41(3-4):214-28.

14. de Hacon SS, Oliveira-Da-costa M, de Gama CS, Ferreira R, Basta PC, Schramm A, et al. Mercury exposure through fish consumption in traditional communities in the Brazilian Northern Amazon. Int J Environ Res Public Health. 2020;17(15):1-15 